\title{
Value Correlation of Deferred Income Tax In Industrialization
}

\author{
Tao Zhang ${ }^{1^{*}}$, Wanzhen $\mathbf{Y u}^{2}$ \\ ${ }^{I}$ School of Economics and Management, Jiangsu University of Science and Technology, Zhenjiang, Jiangsu \\ Province, China \\ ${ }^{2}$ Institute of Taxation, State Administration of Taxation, Yangzhou 225007, China \\ *Corresponding Author.
}

\begin{abstract}
This paper collects 2670 deferred income tax samples from 211 listed industrial companies that have been surviving and continuously disclosing deferred income tax accounting information from 2007 to 2019. On the basis of ohlson model, earnings per share and net flow of operating activities per share are added as adjustment variables to analyze the impact of deferred income tax on stock prices. The results show that:(1) In the long run, DTAs are positively correlated with enterprise stock prices, while DTLs are negatively correlated with enterprise stock prices; (2) After adding the adjustment variable earnings per share, it is found that when EPS level is high, DTAs have a slightly downward negative impact on stock prices, while DTLs have little negative impact on stock prices. When EPS level is low, DTAs have a positive impact on stock prices, while lower earnings per share will accelerate the negative impact of DTLs on stock prices. (3) After adding the adjustment variable CFO, it is found that only when the CFO is sufficient, DTAs are really good news. It has a positive impact on stock price. If the CFO is poor, the positive impact of recognized DTAs on stock price is almost zero. In addition, when the CFO is high, the negative impact of DTLs on price will be accelerated.
\end{abstract}

Keywords: Industrial Development; Value Correlation; Moderating Effect; Deferred Income Tax Asset; Deferred Income Tax Liability; Income Tax Accounting

\section{Introduction}

With the rapid development of industrial industry, people have higher and higher requirements for the quality of income tax accounting information in enterprise statements. Income tax accounting is an accounting theory and method that specializes in studying the difference between accounting income and taxable income of tax law. The resulting income tax accounting standards are more professional and more difficult than other enterprise accounting standards because their contents belong to both tax law issues and tax accounting issues in the accounting field. In 1992, SFAS No.109 was issued by the FASB, it requires enterprises to adopt the balance sheet liability method to fully share the temporary differences between accounting and income tax [1]. In 1996, IFRS No.12 was issued by the IASB, which adopted the Balance Sheet Liability Method proposed by SFAS No.109 [2].The balance sheet liability law requires enterprises to analyze from the balance sheet point of view on the balance sheet date. When the valuation basis of an asset or liability is inconsistent with the tax basis stipulated in the income tax law, calculate and determine the difference between its valuation basis and tax basis, calculate its tax impact according to the applicable income tax rate, and then sum the tax basis and book value. The temporary difference is recognized as a "Deferred Income Tax Assets (DTAs)" or "Deferred Income Tax Liabilities (DTLs)" which is reflected in the balance sheet [3].

On January 1, 2007, the Ministry of Finance of China promulgated the Accounting Standards for Business Enterprises No.18-Income Tax (referred to as Income Tax Accounting Standards), which was the first to be fully implemented in listed companies. The standards standardized the accounting of income tax and the disclosure of relevant information, and it was a major reform in China's income tax accounting. Income tax accounting standards learn from IFRS No.12. It is stipulated that enterprises can only use the balance sheet liability method to calculate income tax, and no longer allow enterprises to choose among tax payable method, deferred method, income statement liability method and balance sheet liability method according to their actual situation, and unified the accounting treatment of enterprise income tax Recognition, measurement and disclosure in China.

ISSN: 0010-8189 


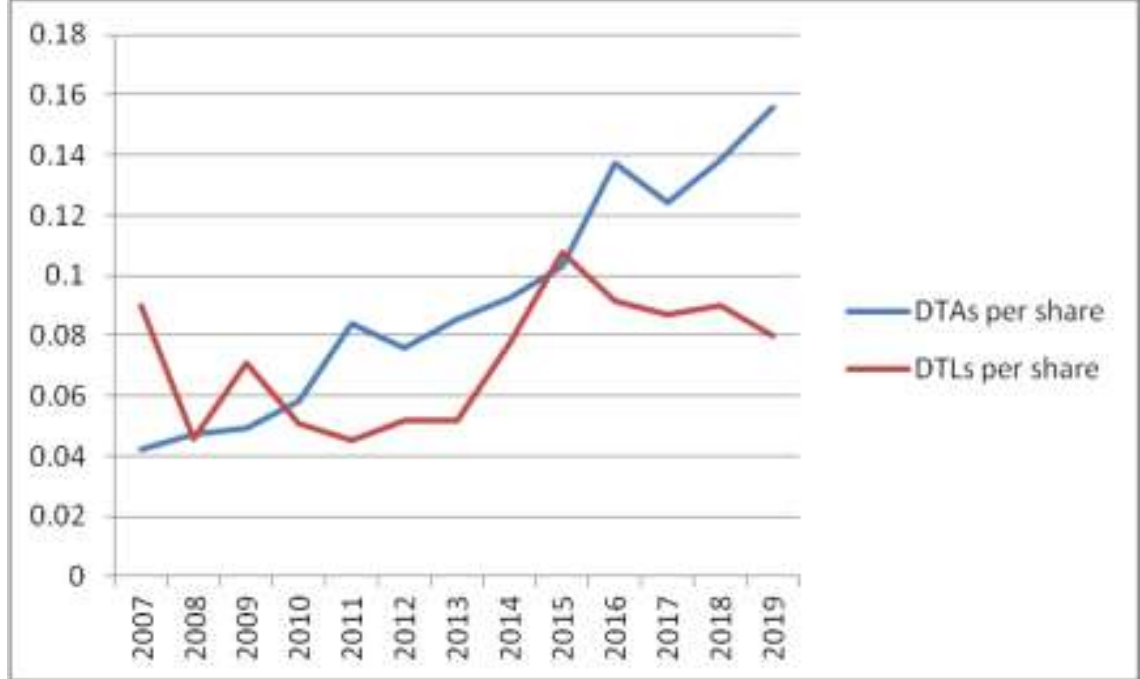

Fig 1 DTAs per share and DTLs per share change line chart

With the implementation of income tax accounting standards in Chinese enterprises, DTAs and DTLs have become the statement items that attract much attention in the balance sheet. Figure 1 (The data were collected from Reith Statistical Database.). It can be seen that from 2007 to 2019, the data of "DTAs" and "DTLs" in the accounting statements are on the rise, especially the DTAs generated by the deductible temporary difference between accounting and tax law, whose amount is much higher than the confirmed amount of DTLs. DTAs is an asset that not only has the function of tax credit in the future, but also has the function of signal, that is, the existence of DTAs indicates that the possibility of revenue in the future will increase, which will have an impact on the expected earnings and stock prices. DTLs is a kind of liability, which has the possibility of paying tax in the future and also has the function of signal, that is, the existence of DTLs indicates that the possibility of expenditure in the future will increase, and it will have an impact on the expected earnings and stock price. DTAs and DTLs contain information not only the increase and decrease of assets and liabilities, but also a centralized embodiment of the collection of many items. Therefore, the research on the impact of deferred income tax on stock prices is very worthy of exploration and attention.

\section{II.Literature Review}

Most developed capitalist countries have a long history of studying deferred income tax, Since the 1970s, many scholars in the United States have studied deferred income tax, which is still the focus of academic research. In 1994, China began to produce income tax accounting, and in 2006, China had its first income tax accounting standard, which required the use of balance sheet liability method to identify DTAs and DTLs. The academic circle began to expand the focus of research to the information on the balance sheet. The results of scholars' research mainly focus on the following three aspects: (1) Most scholars have come to the conclusion that deferred income tax accounting information is related to stock price. Beaver and Dukes (1972) [4], Dan and Hayn (1992) [5], Amir (1997) [6], Ayers (1998) [7], Chang, Herbohn and Tutticci (2009) [8], Li Lijuan (2011) [9], Zheng Lidong (2012) [10], Tian Juan (2015) Deferred income tax information improves the quality of accounting information. (2) A few scholars disapprove of the disclosure of deferred income tax information. Chandra and RO (1997) [12], Beckman, Brandes and Eierle (2007) [13], Chludek (2011) [14]think that DTAs or DTLs are highly uncertain for future cash flows, and their present value is close to zero, which has no correlation with stock prices.(3) Research on deferred income tax accounting information and enterprise earnings management. Dai Deming et al. (2013) [15], Gaidi (2014) [16], Wan Shuangting. (2018) [17] pointed out that although deferred income tax accounting information increases the information of future cash flow changes in accounting statements, a large number of DTAs will greatly increase the assets of enterprises. If they cannot be reversed in the following years, they are not real. It is easy to provide enterprise managers with space for earnings management.

The research results on the correlation between deferred income tax accounting information and stock price at home

ISSN: 0010-8189 
and abroad are fruitful, which lays a good foundation for follow-up research, but there is still room for further deepening and expanding. The main manifestations are as follows: (1) Chinese scholars' research data collection on the correlation between deferred income tax accounting information and stock price mostly takes 3-7 years, It is difficult to judge the long-term and stability of its research results. (2) The existing researches are all about the relationship between deferred income tax accounting information and stock price alone, without discussing whether there are other factors that will affect the relationship between deferred income tax accounting information and stock price. In this context, this paper adopts the relevant data of a long period (2007-2019) after the implementation of the income tax accounting standards. This paper examines the long-term trend of correlation between deferred income tax accounting information and stock price of A-share listed companies in Shanghai stock market, and studies the influence of DTAs and DTLs on stock price since the implementation of income tax accounting standards. So as to supplement the existing research results and obtain more complete conclusions, so that the demanders of accounting information can better interpret and use the deferred income tax accounting information for analysis and decision-making.

\section{Theory and Hypothesis}

"Decision usefulness of accounting information" requires that the accounting information disclosed by companies is closely related to investors' investment decisions and can help investors make correct decisions [18]. Information demanders can predict the future development of enterprises. Comprehensive, systematic, timely and accurate reflection of enterprise assets, liabilities, income and expenses is one of the basic functions of accounting. These accounting information has become a medium for information users to understand the financial status and operating results of enterprises. If accounting information have an impact on evaluation activities or current and future decision-making results, such accounting information will relevant. The research on the value relevance of accounting information originates from the financial reporting goal of decision usefulness and the efficient market hypothesis. In 1965, Fama pointed out in the efficient market hypothesis that as long as the market is completely efficient, what happened or expected to happen in an enterprise can be reflected by the price of a single stock. Investors can also analyze the real profitability of the company in the future according to the accounting information disclosed in the financial report. According to the degree of information disclosure, the market can be divided into weak efficient, semi-strong efficient and strong efficient. China's existing capital market can satisfy the semi-strong efficient market in the efficient market hypothesis, and its accounting information can be reflected in the market. Accounting information will have an impact on stock prices.

Ball and Brown (1968) [19]adopted the method of event study at the same time, which linked the disclosure of accounting earnings information with the change of stock price, and confirmed that financial reports have certain information content. Subsequently, Beaver, Clarke and Wright (1979) [20] selected the accounting data of 276 listed companies in the United States from 1965 to 1974.It is verified that there is a significant positive correlation between accounting surplus figures and stock prices, that is, the higher the number of accounting surplus, the greater the stock value, which initiated the research of accounting surplus information. Assets are defined in China's Accounting Standards for Business Enterprises as: Formed by past transactions or events of an enterprise, owned or controlled by an enterprise, Resources expected to bring economic benefits to enterprises. Assets are resources that are expected to bring economic benefits to enterprises, that is to say, investors can estimate the expected company's accounting surplus according to the accounting information provided by assets. Under the background of information view, assets are related to the future accounting surplus chain for investors. The future accounting surplus chain is related to the future dividend chain, which determines the value of stocks, so the accounting information provided by assets is also related to the value of stocks. The commonly used classic model for the correlation research of accounting information is the price model [21]. The price model, based on accounting measurement, and directly calculates the stock price by using accounting information, which is a great development of the stock value evaluation model. In the classical price model, it is proved that the intrinsic value of current stock can be expressed by net assets per share (BV) at the end of the period and earnings per share (EPS) at the current period. This research provides a theoretical basis for the relationship between current accounting information and intrinsic value of stock, and also opens a way for the research of the relationship between current accounting information and intrinsic value of stock. The purpose

ISSN: 0010-8189 
of implementing the income tax accounting standards in 2007 is to better coordinate the differences between accounting and taxation in the recognition and measurement of income and expenses, and to improve the income tax treatment methods. Under the balance sheet liability method, the temporary difference between accounting and taxation is recognized as DTAs and DTLs, which are listed separately, and the difference between them is taken as a part of income tax expenses. Since then, the accounting information of deferred income tax has been included in the net assets per share and earnings per share of the enterprise balance sheet items. In order to better test the value relevance of the accounting information of deferred income tax and the incremental information provided by deferred income tax, we should eliminate the accounting information of deferred income tax contained in its variables, or the result of the test may be weakening. Here, BV and EPS are the parts after deducting the influence of deferred income tax items, and there is still a correlation between them and stock prices. Therefore, put forward hypothesis 1:

Hypothesis 1: There is a correlation between adjusted BV and stock price, and there is also a correlation between adjusted EPS and stock price.

The recognition of deferred income tax expenses from the perspective of assets and liabilities improves the information quality of the balance sheet and income statement published by enterprises. The accounting goal has shifted from providing information to the internal of enterprises to meeting the information needs of external investors and shareholders. Compared with the cash flow information disclosed by enterprises, deferred income tax is related Accrual information can provide enterprises with incremental accounting information.

The new item "DTAs" is the tax inflow of enterprises in the future confirmed by deductible temporary differences according to the expected tax rate, which indicates that enterprises bring economic benefits and the inflow of future cash flows. "DTLs" is the tax expenditure of the enterprise in the future period confirmed according to the estimated tax rate corresponding to the temporary tax difference, which shows the burden of the enterprise and is the outflow of future cash flow. It can be concluded that the larger the company's DTAs are, the smaller the future cash outflow will be. Investors will be optimistic about the company's future earnings and increase their investment in the company, and the company's stock price will increase. On the contrary, the greater the company's DTLs, investors will be pessimistic about the company's future operations, and the company's share price will decrease accordingly. Therefore, put forward hypothesis 2 :

Hypothesis 2: There is a positive correlation between DTAs and stock prices, and there is a negative correlation between DTLs and stock prices.

It has been agreed that there is a significant positive correlation between accounting earnings per share and stock price. But accounting earnings based on the accrual basis, sometimes enterprises can through the adjustment of the accounting policies and accounting estimates to control the accounting earnings; Cash flow is based on cash basis, which can more accurately reflect the cash flow and solvency of enterprises, and it is not easy to manipulate, so it has a complementary role for investors to make decisions. Cash flow can bring incremental value relevance and further improve the explanatory power of stock price [22]. When temporary surplus accounts for a large proportion of accounting earnings, investors are more inclined to use cash flow to make investment decisions. Cash flow can be divided into cash flow from operating activities, cash flow from investment activities and cash flow from fund-raising activities. People often regard cash flow from operating activities as an important reference index for evaluating stock value, because the cash flow index from operating activities is not affected by cost confirmation methods or depreciation, and it is more difficult to be controlled by the management than the profit, The net cash flow from operating activities per share (CFO) can have an impact on the stock price, and this impact is increasing year by year [23]. Therefore, this paper puts forward Hypothesis 3:

Hypothesis 3: There is a positive correlation between CFO and stock price.

There are many factors that affect stock prices, but the main factors can be summarized into two categories: current enterprise performance and future development potential. Among them, EPS is the strongest embodiment of the

ISSN: 0010-8189 
current performance of the enterprise, which reflects the enterprise profits or losses that ordinary shareholders can enjoy for each share of the enterprise, directly reflects the profitability of ordinary shares, and represents the profitability of the enterprise. EPS is an important index that comprehensively reflects the profitability of a company. It can be used to evaluate the operating performance of management departments and make the performance of companies with different scales and different capital structures comparable. It is found that the accounting earnings information provided by companies with increasing earnings per share has stronger persistence and higher information quality [24].

As a new item in the report, although" DTAs" has all the characteristics of assets, but because it is embodied in the potential of the future development of the enterprise, whether it can bring real benefits to the enterprise in the future will be affected by the actual profitability. The higher EPS, the more likely the deferred tax asset is to be realized, and the greater its positive impact on the price. "DTLs" represent the outflow of future economic benefits, which will have a negative impact on stock prices, while earnings per share, as a display of management efficiency, profitability and dividend distribution sources, will also affect the impact of DTLs on stock prices. When EPS of the enterprise is relatively low, and the DTLs are high at this time, it means that not only the profit level of common stock is poor at present, but also the growth of the enterprise for development is relatively poor. At this time, the DTLs will strengthen the unfavorable signal, resulting in a sharp drop in stock prices; On the contrary, when EPS of the enterprise is relatively high, although the DTLs are relatively high, there will be an outflow of economic benefits. However, due to the high profit level of common stock, the unfavorable signal brought by DTLs will be absorbed by the higher earnings per share, so the stock price will not fall sharply. Therefore, put forward hypothesis 4 :

Hypothesis 4: Higher EPS will enhance the positive impact of DTAs on stock prices, while lower EPS will enhance the negative impact of DTLs on stock prices.

The balance sheet liability method starts from the balance sheet in the confirmation and measurement of deferred income tax accounting information. By analyzing the reasons and nature of differences between accounting and tax law, according to the expected tax rate during the reversal of differences and the impact on future enterprise income tax, they are respectively recognized as DTAs or DTLs and which are listed separately in the balance sheet. The recognition of DTAs should be based on the realization of sufficient taxable income in the future.

The CFO represents the actual hematopoietic function of the enterprise. The greater the CFO, the stronger the actual profit level of the enterprise, which is a powerful guarantee for the enterprise to realize the full amount of taxable income in the future. The DTAs confirmed at this time truly represent the future cash inflow of the enterprise and will have a positive impact on the stock price.

If the net cash flow per share of business activities is very small, which shows that the actual profitability of the enterprise is poor, and there may not be enough taxable income in the future period, which can be used for pre-tax deduction of DTAs. At this time, the correlation between DTAs and stock prices is poor. When the net cash flow per share of business activities is low, DTLs will appear to further strengthen the unfavorable signal of the future of enterprises, resulting in a sharp drop in stock prices. Therefore, put forward hypothesis 5:

Hypothesis 5: The higher the CFO will enhance the positive impact of DTAs on stock prices, while the lower the CFO will enhance the negative impact of DTLs on stock prices.

\section{Materials and Methods}

This paper studies the correlation between income tax accounting information and stock price of China's A-share listed companies. In fact, it examines the relationship between stock price of A-share listed companies and DTAs and DTLs. The specific variables are shown in Table 1.

The above variables are the concept of each share. In order to eliminate the data and eliminate the influence of

ISSN: 0010-8189 
dimension and order of magnitude, the original data is standardized; then take logarithm to eliminate heteroscedasticity. In the process of modeling and analysis, Ohlson classical price model is used for regression analysis. The price model proves and describes the relationship among company value, net assets and earnings per share with a mathematical model. The basic price model is:

$$
\text { Pit }=\beta 0+\beta 1 \text { BVit }+\beta 2 \text { Eit }+\varepsilon
$$

Among them, Pit is the stock price of listed company I in the $t$ year. This paper selects the stock closing price of listed company on April 30th every year to participate in the empirical analysis. On the one hand, choosing the same day's data can increase the comparability of accounting information, on the other hand, April 30th is the publication deadline of listed company's annual report. Choosing this day's stock price to participate in the analysis can reflect the publication of the annual report more objectively after the market reaction. The size of $\beta$ coefficient represents the degree to which independent variables explain stock prices: if $\beta$ value is positive, it will have a positive impact on stock prices, otherwise it will have a negative impact on stock prices. BVit is the net assets per share of listed company $i$ in year $t$, Eit is EPS of listed company $i$ in year $t, \varepsilon$ is the model residual. In addition, after excluding the deferred income tax accounting information contained in earnings per share and net profit, a new price model is obtained on the basis of the basic price model:

$$
\text { Pit }=\beta 0+\beta 1 \text { Adj_BVit }+\beta 2 \text { Adj_Eit }+\varepsilon
$$

\begin{tabular}{|c|c|c|}
\hline $\begin{array}{l}\text { Variable } \\
\text { code }\end{array}$ & Variable name & Describe \\
\hline Pit & Price per share & Closing price of listed company $i$ on April 30th of the first year \\
\hline BVit & Net assets per share & Net assets per share of listed company $i$ at the end of year $t$ \\
\hline Eit & Earnings per share & Earnings per share of listed company $i$ at the end of the $t$ year \\
\hline DTAit & $\begin{array}{l}\text { Deferred income tax } \\
\text { assets per share }\end{array}$ & Deferred income tax assets per share of listed company $i$ at the end of year $t$ \\
\hline DTLit & $\begin{array}{l}\text { Deferred income tax } \\
\text { liabilities per }\end{array}$ & Deferred income tax liabilities per share of listed company $i$ at the end of year \\
\hline CFOit & $\begin{array}{c}\text { Net flow of } \\
\text { operating activities }\end{array}$ & $\begin{array}{l}\text { Net inflow of operating activities per share of listed company } i \text { at the end of the } \\
\text { t year }\end{array}$ \\
\hline Adj_BVit & $\begin{array}{l}\text { Adjusted net assets } \\
\text { per share }\end{array}$ & $\begin{array}{c}\text { The net assets per share of listed company } i \text { at the end of year t-(DTAs per } \\
\text { share of listed company } i \text { at the end of year t-DTLs per share of listed company } \\
i \text { at the end of year } t)\end{array}$ \\
\hline Adj_Eit & $\begin{array}{l}\text { Adjusted earnings } \\
\text { per share }\end{array}$ & $\begin{array}{l}\text { Earnings per share of listed company I at the end of year t-(DTAs per share of } \\
\text { listed company } i \text { at the end of year t-DTLs per share of listed company } i \text { at the } \\
\text { end of year } t)\end{array}$ \\
\hline
\end{tabular}

Table 1 Variable Definition Table

When studying deferred income tax accounting information, because it contains two different parts: DTAs and DTLs, we will study them separately and use them as two independent variables for regression analysis, while the net operating cash flow per share, as another important factor affecting the price, is added to the model as a control variable in this paper Medium. Therefore, the following model is established on the basis of model (2):

$$
\text { Pit }=\beta 0+\beta 1 \text { Adj_BVit }+\beta 2 \text { Adj_Eit }+\beta 3 \text { DTAit }+\beta 4 \text { DTLit }+\beta 5 \text { CFOit } \varepsilon
$$

In addition, in order to further analyze the relationship between EPS, DTAs and DTLs, the following model is established on the basis of model (3):

Pit $=\beta 0+\beta 1$ Adj_BVit $+\beta 2$ Adj_Eit $+\beta 3$ DTAit $+\beta 4$ DTLit $+\beta 5$ CFOit $\varepsilon+\beta 6$ Adj_EitDTAit $+\beta 7$ Adj_EitDTLit $+\varepsilon(4)$

In order to further analyze the relationship between operating net cash flow per share and DTAs, the following model is established on the basis of model(4):

Pit $=\beta 0+\beta 1$ Adj_BVit $+\beta 2$ Adj_Eit $+\beta 3$ DTAit $+\beta 4$ DTLit $+\beta 5$ NCFit $\varepsilon+\beta 6$ Adj_EitDTAit $+\beta 7$ Adj_EitDTLit $+\beta 8$ Adj_CFOi

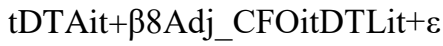




\section{Empirical Analysis}

\subsection{Sample Selection and Data Sources}

This paper mainly collects data from the statistics database of RuiSi. Some data are directly collected from the financial statements of listed companies disclosed by Shanghai Stock Exchange. In this paper, A-share companies listed in China's Shanghai Stock Exchange from 2007 to 2019 are selected as samples, and the effective sample size is 2670 . In the sample selection, this paper follows the following principles:

(1) The sample selected the enterprises that have been surviving from 2007 to 2019 and continuously disclosed DTAs and DTLs, and excluded the newly established and delisted enterprises.

(2) The data in the financial statements are complete, and the missing stock price or incomplete financial data (such as the missing data of DTAs, DTLs, accounting earnings, etc.) caused by the suspension of listing of the company are not selected as samples.

(3) Financial enterprises were deleted from the sample. Because the business model of financial listed companies is different from other listed companies, and the structure and content of accounting statements are also different from other companies, the data of financial listed companies will affect the results of empirical test. Therefore, it was not selected as a sample.

(4) Enterprises with negative net assets per share and negative earnings per share were deleted from the sample. On the one hand, EPS represents the earnings earned after the operation of funds. If EPS is negative, it means that the operation of listed companies is at a loss, and investors are not interested in their investment, so this sample has no significance for analysis. On the other hand, it has been proved by scholars that enterprises with positive sustainable profitability provide higher quality accounting earnings information. Therefore, we exclude the listed companies with negative BV and negative EPS. The final number of samples is 2670 .

\subsection{Results and Analysis of Empirical Research}

\subsubsection{Descriptive statistics}

In order to eliminate the influence of dimension and order of magnitude on data, the original data is standardized, and then logarithm is taken to eliminate heteroscedasticity. The following conclusions can be drawn from Table 2: (1) The average stock price of sample companies is 1.0460 , and the average net assets per share is 0.6346 . The average earnings per share is 0.1557 . (2) The average value of DTLs is 0.0231 , and the average value of DTAs is 0.0327 , the amount of DTAs confirmed is greater than the amount of DTLs.

Table 2 Descriptive statistics of variables

\begin{tabular}{c|c|c|c|c|c}
\hline & $\mathrm{N}$ & Minimum & maximum & Mean & $\begin{array}{c}\text { SD } \\
\text { deviation }\end{array}$ \\
\hline $\log$ EEit & 2670 & -1.2749 & 1.4500 & 0.1557 & 0.1363 \\
\hline $\log$ DTAit & 2670 & 0.0000 & 0.5303 & 0.0327 & 0.0523 \\
\hline $\log$ DTLit & 2670 & 0.0000 & 0.8133 & 0.0231 & 0.0639 \\
\hline log_CFOit & 2670 & -1.5258 & 1.5797 & 0.4145 & 0.2035 \\
\hline Effective number & 2670 & & & & \\
\hline
\end{tabular}

5.2.2 Pearson correlation test

Table 3 Correlation coefficient table

\begin{tabular}{c|c|c|c|c|c}
\hline variable & log_Pit & log_BVit & $\log$ Eit & log_DTAit & log_DTLit \\
\hline log_Pit & 1 & & & & \\
\hline log_BVit & $.435^{* *}$ & 1 & & & \\
\hline
\end{tabular}

ISSN: 0010-8189

(C) CONVERTER 2020 


\begin{tabular}{c|c|c|c|c|c}
\hline $\log$ EEit & $.560^{* *}$ & $.609 * *$ & 1 & & \\
\hline $\log$ DDTAit & $.174 * *$ & $.428^{* *}$ & $.185^{* *}$ & 1 & \\
\hline $\log$ _DTLit & $.009 * *$ & $.277 * *$ & $.370 * *$ & $.238^{* *}$ & 1 \\
\hline $\log$ CFOit & $.266^{* *}$ & $267 * *$ & $255^{* *}$ & $167 * *$ & $-.026^{* *}$ \\
\hline
\end{tabular}

**. Significant correlation at 0.01 level (bilateral); *. Significant correlation at 0.05 level (bilateral)

Before regression test, Pearson test analysis should be carried out on the variables involved in the model. According to Table 3, the following conclusions are drawn: (1)There is a significant positive linear correlation between stock price and other major variables, and the significant level is at the level of 5\%; (2)There is a significant positive linear correlation between net assets per share and other major variables, and the significant level is at $1 \%$; (3)There is a significant positive linear correlation between earnings per share and other major variables, and the significant level is at $1 \%$; (4)There is a significant positive linear correlation between DTAs per share and other major variables, and the significant level is at $1 \%$; (5) Other main variables of net flow of operating activities per share have significant positive linear correlation, and the significant level is at 1\%; (6)DTAs per share have significant correlation with stock price, net assets per share, earnings per share and DTAs per share.

5.2.3 Analysis of stratified regression results

Table 4 Stratified regression results

\begin{tabular}{|c|c|c|c|c|c|c|c|c|}
\hline & \multicolumn{8}{|c|}{ Price(log_P) } \\
\hline & \multicolumn{2}{|c|}{ Model 2} & \multicolumn{2}{|c|}{ Model 3} & \multicolumn{2}{|c|}{ Model 4} & \multicolumn{2}{|c|}{ Model 5} \\
\hline & $\begin{array}{c}\text { Coefficient } \\
\text { (T) }\end{array}$ & Sig & $\begin{array}{c}\text { Coefficient } \\
\text { (T) }\end{array}$ & Sig & $\begin{array}{c}\text { Coefficient } \\
\text { (T) }\end{array}$ & Sig & $\begin{array}{c}\text { Coefficient } \\
\text { (T) }\end{array}$ & Sig \\
\hline $\mathrm{C}$ (constant) & $\begin{array}{c}0.758 \\
(53.13)\end{array}$ & .000 & $\begin{array}{c}0.720 \\
(46.20)\end{array}$ & .000 & $\begin{array}{c}0.716 \\
(46.53)\end{array}$ & .000 & $\begin{array}{c}0.769 \\
(45.47)\end{array}$ & .000 \\
\hline log_BVit & $\begin{array}{l}0.195 \\
(7.51) \\
\end{array}$ & .000 & $\begin{array}{l}0.160 \\
(5.87) \\
\end{array}$ & .000 & $\begin{array}{l}0.113 \\
(4.12) \\
\end{array}$ & .000 & $\begin{array}{l}0.112 \\
(4.08) \\
\end{array}$ & .000 \\
\hline log_Eit & $\begin{array}{c}1.058 \\
(23.39) \\
\end{array}$ & .000 & $\begin{array}{c}1.223 \\
(28.56) \\
\end{array}$ & .000 & $\begin{array}{c}1.475 \\
(9.919) \\
\end{array}$ & .000 & $\begin{array}{c}1.13 \\
(9.684) \\
\end{array}$ & .000 \\
\hline Log_DTAit & & & $\begin{array}{l}0.406 \\
(3.78) \\
\end{array}$ & .000 & $\begin{array}{l}0.680 \\
(6.17) \\
\end{array}$ & .000 & $\begin{array}{l}0.577 \\
(5.07) \\
\end{array}$ & .000 \\
\hline Log_DTLit & & & $\begin{array}{c}-1.214 \\
(-14.16) \\
\end{array}$ & .000 & $\begin{array}{c}-1.779 \\
(-12.25)\end{array}$ & .000 & $\begin{array}{c}-1.817 \\
(-12.37) \\
\end{array}$ & .000 \\
\hline Log_CFOit & & & $\begin{array}{l}0.117 \\
(4.80)\end{array}$ & .000 & $\begin{array}{l}0.110 \\
(4.58)\end{array}$ & .000 & $\begin{array}{l}0.137 \\
(3.21)\end{array}$ & .000 \\
\hline Log_Eitlog_DTAit & & & & & $\begin{array}{l}-2.264 \\
(-8.48)\end{array}$ & .000 & $\begin{array}{l}-2.480 \\
(-9.09)\end{array}$ & .000 \\
\hline Log_Eitlog_DTLit & & & & & $\begin{array}{l}1.622 \\
(3.59)\end{array}$ & .000 & $\begin{array}{l}1.849 \\
(4.02)\end{array}$ & .000 \\
\hline Log_CFOitlog_DTAit & & & & & & & $\begin{array}{l}0.794 \\
(3.29)\end{array}$ & .001 \\
\hline Log_CFOitlog_DTLit & & & & & & & $\begin{array}{l}-0.879 \\
(-2.67) \\
\end{array}$ & .008 \\
\hline $\mathrm{R} 2$ & \multicolumn{2}{|c|}{0.572} & \multicolumn{2}{|c|}{0.621} & \multicolumn{2}{|c|}{0.636} & \multicolumn{2}{|c|}{0.639} \\
\hline
\end{tabular}

Dependent Variable: $\log _{-} \mathrm{P}$

After the correlation analysis of sample data, based on the model established above, SPSS19.0 is used forregression analysis verify the hypothesis. It can be seen from Table 4 that the adjusted net assets per share and earnings per share have a positive correlation on the price, and Hypothesis 1 passes the verification. On the basis of model (2), after adding DTAs, DTLs and net flow of operating activities per share, it shows that DTAs are positively correlated with ISSN: 0010-8189 
stock price, net flow of operating activities per share is positively correlated with stock price, DTLs are negatively correlated with stock price, and R2rises from 0.572 to 0.621 , the fitting degree of the equation is improved, and Hypothesis 2 and Hypothesis 3 are verified. The adjustment effect test of earnings per share. On the basis of model (3), after adding the product of earnings per share and deferred income tax accounting information, the R2is 0.636 , the fitting degree of the equation is improved, and the adjustment effect exists. See Figure 2 and Figure 3 for the specific impact.

It can be seen from Figure 2 that when the company's earnings per share are high, the impact of DTAs on stock prices shows a slight downward negative impact (red line inclines downward). Because the realization of DTAs should be guaranteed by future income, the higher the DTAs, means that the future must have a greater amount of taxable income to enables the DTAs back to a pre-tax deduction.

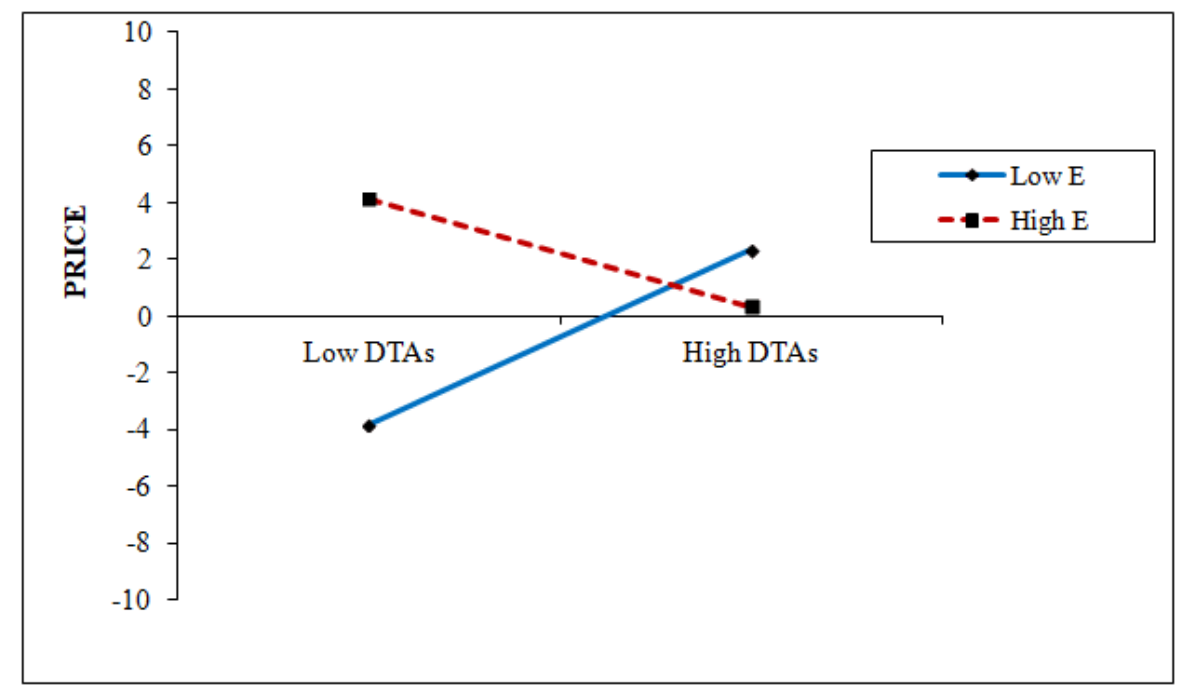

Figure 2 Adjustment chart of EPS in relation to DTAs and $P$

When the enterprise have been under higher returns, the pressure to keep the income rising will be relatively large, so the excessive DTAs will have a negative impact on the stock price. When EPS of enterprises are low, DTAs, as future gains, release the possibility of future cash inflow increase, which has a positive impact on stock prices (the blue line presents a positive slope). The test results also reveal the reasons why enterprises with weak profitability are keen to confirm DTAs during the implementation of income tax standards in China.

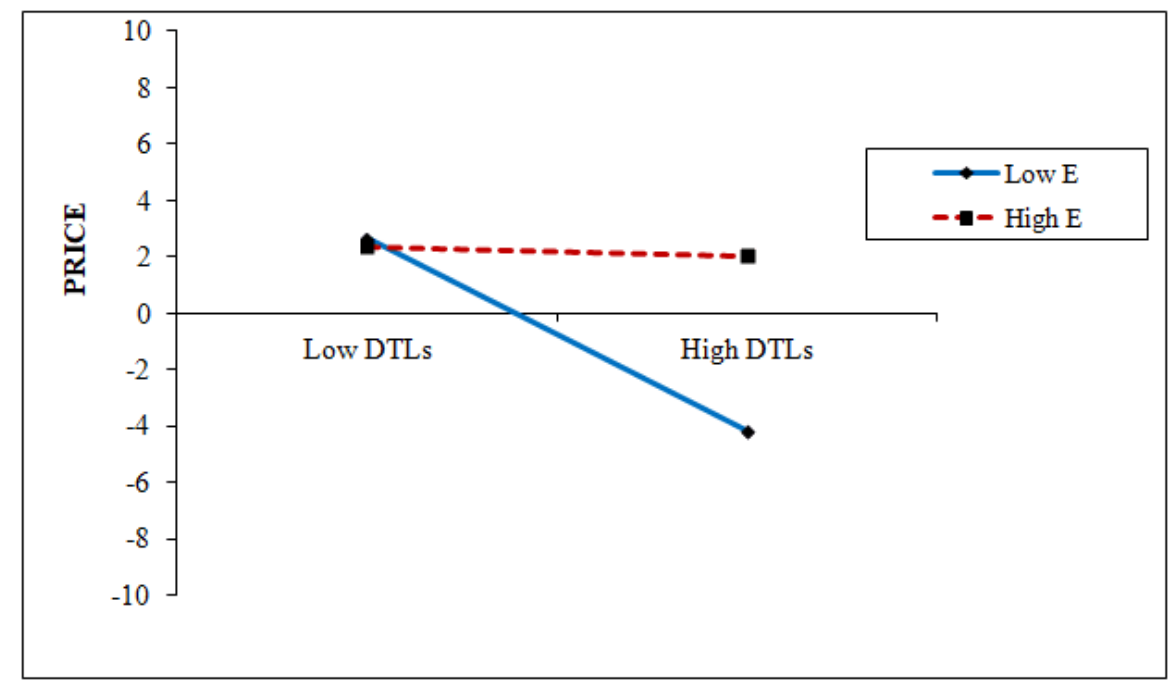

Figure 3 Adjustment chart of EPS in relation to DTLs and P 
It can be seen from Figure 3 that when EPS of enterprises are relatively low, the DTLs have a great impact on stock prices. The higher the DTLs, the greater the negative slope of the blue line. When EPS of enterprises are relatively high, the impact of DTLs on stock prices is negative, but due to higher earnings per share, Absorb some unfavorable factors (the negative slope of the red line is small), thus making the decline of stock price moderate. Suppose four parts pass the test. Hypothesis 4 partially passes the test.

Whether the production of business activities can produce enough cash determines whether the DTAs can really flow into the enterprise in the future. On the basis of model (4), the product of net flow of business activities per share and deferred income tax accounting information is added. After further analysis, R2is 0.639, which improves the fitting degree of the equation, indicating that the CFO plays a regulatory role between the accounting information of deferred income tax and the price. Figure 4 shows that when the net cash flow from business activities is low, the increase in the number of DTAs has little effect on the stock price, and even has a downward negative impact. At this time, DTAs are not assets has little effect on the stock price, and even has a downward negative impact. At this time, DTAs are not a real project that can bring benefits, and there is no correlation. Only when the net cash flow of operating activities is sufficient, with the increase of deferred tax assets, will the enterprise bring positive information and increase the stock price. At this time, the future income shown by deferred tax assets can be truly realized under the condition of sufficient net cash flow of operating activities.

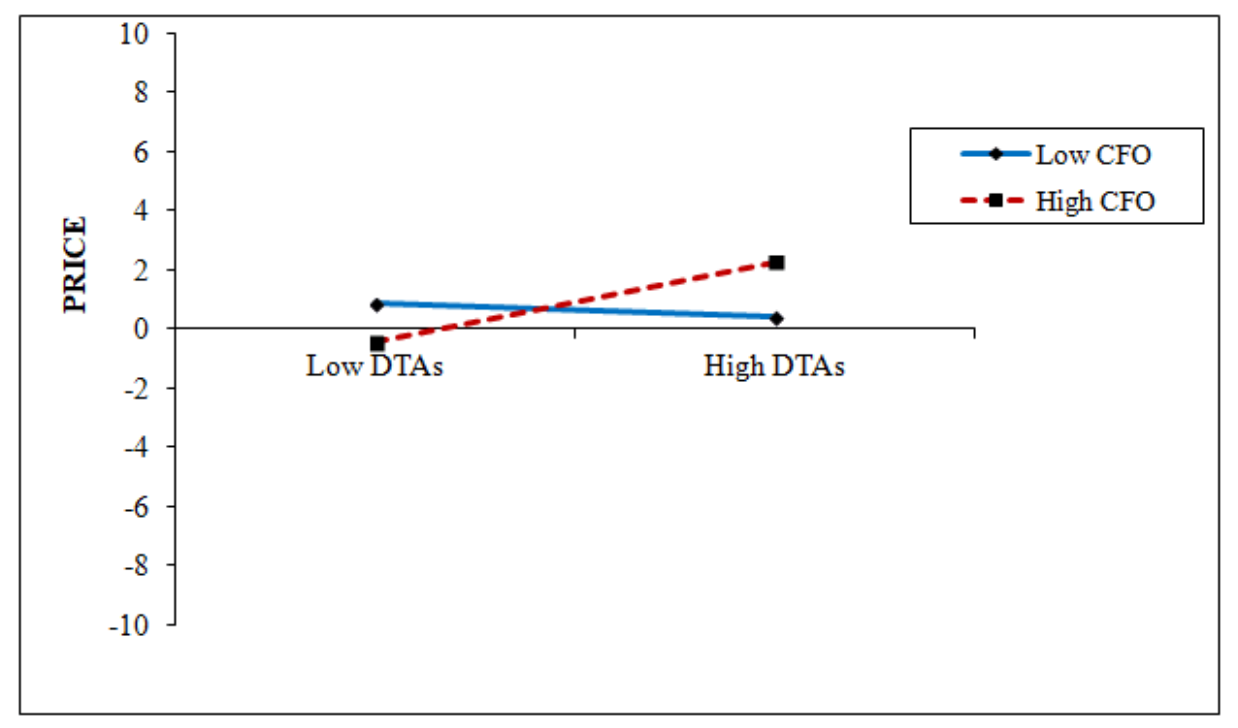

Figure 4 Adjustment chart of CFO in the relationship between DTAs and $P$

Figure 5 shows that deferred income tax is the burden of enterprises, and the increase of DTLs will lead to the decline of stock prices. When the net cash flow of operating activities per share is large, the market is more sensitive to the negative impact of DTLs, and its price declines faster. This is because under the condition of good net cash flow of operating activities in this period, if the amount of deferred tax liabilities is high, the pressure to maintain high net cash flow of operating activities in the future will be greater. At this time, a large number of DTLs will lead to a rapid decline in stock prices. 


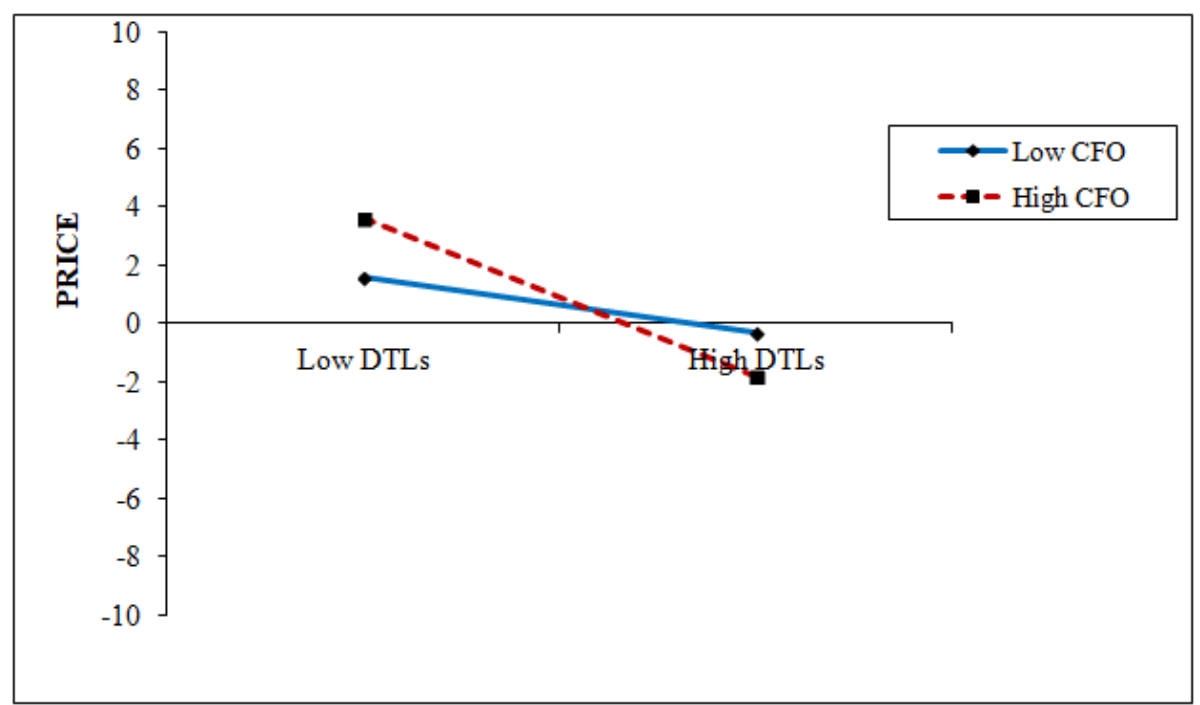

Figure 5 Adjustment chart of net CFO in the relationship between DTLs and P

\section{Robustness Test}

The data collected in this paper involve different enterprises in 14 industries, including manufacturing, real estate and transportation, among which manufacturing companies have the largest number. In order to further verify the regression results, the existing data are divided into manufacturing and non-manufacturing industries for regression analysis, and then verify whether there will be new changes in the impact of deferred income tax accounting information and stock prices after enterprises are divided into industries. Descriptive statistics of sample variables in manufacturing industry

The descriptive statistics of manufacturing industry in Table 5 show that the average value of DTAs per share in manufacturing enterprises is obviously greater than the average value of DTLs per share, and the deferred income assets due to deductible temporary differences in manufacturing enterprises are much higher than those due to taxable temporary differences. Table 6 carries out descriptive statistics on non-manufacturing enterprises first. It can be seen that the average value of DTAs per share in non-manufacturing enterprises is basically the same as the average value of DTLs per share. Generally speaking, non-manufacturing enterprises have little impact on their net profit due to deferred income tax. In order to test the nature of the industry in which the enterprise is located, whether it will affect the impact of deferred income tax on its value relevance, the regression analysis of models (2), (3), (4) and (5) is carried out by industry.

Table 5 Descriptive statistics of sample variables in manufacturing industry

\begin{tabular}{l|c|c|c|c|c}
\hline & $\mathrm{N}$ & Minimum & maximum & Mean & $\begin{array}{c}\text { SD } \\
\text {. }\end{array}$ \\
\hline log_Pit & 1201 & 0.4200 & 3.1023 & 1.1305 & 0.3259 \\
\hline log_BVit & 1201 & -0.1309 & 1.9667 & 0.6474 & 0.2407 \\
\hline log_Eit & 1201 & -0.7908 & 1.4500 & 0.1613 & 0.1483 \\
\hline log_DTAit & 1201 & 0.0000 & 0.5303 & 0.0337 & 0.0506 \\
\hline log_DTLit & 1201 & 0.0000 & 0.2826 & 0.0098 & 0.0248 \\
\hline log_CFOit & 1201 & -0.8775 & 1.5797 & 0.4295 & 0.1853 \\
\hline Effective number & 1201 & & & & \\
\hline
\end{tabular}

Table 6 Descriptive statistics of sample variables in non-manufacturing industry

\begin{tabular}{l|l|l|l|l|l|}
\hline & $\mathrm{N}$ & Minimum & maximum & Mean & SD . \\
\hline
\end{tabular}

ISSN: 0010-8189 


\begin{tabular}{l|l|l|l|l|c}
\hline log_Pit & 1468 & 0.2833 & 2.0968 & 0.9772 & 0.2683 \\
\hline $\log$ BVit & 1468 & -0.3773 & 1.4207 & 0.6287 & 0.2342 \\
\hline $\log$ Eit & 1468 & -1.2749 & 0.8427 & 0.1516 & 0.1259 \\
\hline log_DTAit4 & 1468 & 0.0000 & 0.8133 & 0.0350 & 0.0536 \\
\hline $\log$ DTLit & 1468 & 0.0000 & 1.2627 & 0.0355 & 0.0808 \\
\hline log_CFOit & 1468 & -1.5258 & 1.5797 & 0.4025 & 0.2130 \\
\hline Effective number & 1468 & & & & \\
\hline
\end{tabular}

The test results show that the adjusted net assets per share and earnings per share still have a positive correlation with prices in manufacturing industry, while DTAs have a positive correlation with stock prices, while DTLs have a negative correlation with stock prices. Earnings per share and net flow of operating activities per share also have a moderating effect on deferred income tax. However, in the test of non-manufacturing enterprises, the negative correlation between DTLs and prices has passed the test, but there is no significant correlation between DTAs and stock prices, and DTAs have not passed the hypothesis test. After further analyzing the sample data of enterprises, it is found that in the non-manufacturing data, the number of enterprises in the real estate industry accounts for a higher proportion. The real estate industry is a very large industry of pre-sale business, most of the sales business are carried out by the way of pre-sale and collection.

Although before the completion and acceptance of the project, the accounting will not be confirmed as the income of the enterprise, but the tax law, for this part of the pre-sale business received the advance payment, the need to estimate the sales gross profit and included in the current taxable income, which leads to the formation of DTAs. However, when this part of DTAs is realized in the future and DTAs are turned back, because the funds have already flowed into the enterprise when the accounts received in advance are collected, it will not bring about an increase in cash inflow. Therefore, the DTAs generated by the accounts received in advance are not highly correlated with prices. In other enterprises with low proportion of accounts received in advance, DTAs still play a signal role and have a positive correlation with stock price. The basic conclusion of this paper is robust.

Table 7 Regression results by sector

\begin{tabular}{|c|c|c|c|c|c|c|c|c|}
\hline & \multicolumn{8}{|c|}{ Price(log_P) } \\
\hline & \multicolumn{4}{|c|}{$\begin{array}{c}\text { Manufacturing coefficient } \\
(\mathrm{T})\end{array}$} & \multicolumn{4}{|c|}{$\begin{array}{c}\text { Non-manufacturing coefficient } \\
(\mathrm{T})\end{array}$} \\
\hline & Model 2 & Model 3 & Model 4 & Model 5 & Model 2 & Model 3 & Model 4 & Model 5 \\
\hline log_BVit & $\begin{array}{l}0.219 \\
(6.01)\end{array}$ & $\begin{array}{l}.0199 \\
(5.15)\end{array}$ & $\begin{array}{l}0.152 \\
(3.94)\end{array}$ & $\begin{array}{l}0.153 \\
(3.95)\end{array}$ & $\begin{array}{l}0.165 \\
(4.91)\end{array}$ & $\begin{array}{l}0.159 \\
(4.00)\end{array}$ & $\begin{array}{l}0.087 \\
(2.33)\end{array}$ & $\begin{array}{l}.087 \\
(2.33)\end{array}$ \\
\hline log_Eit & $\begin{array}{l}1.228 \\
(21.93)\end{array}$ & $\begin{array}{l}1.300 \\
(22.27)\end{array}$ & $\begin{array}{l}1.550 \\
(21.04)\end{array}$ & $\begin{array}{c}1.519 \\
(21.21)\end{array}$ & $\begin{array}{c}0.756 \\
(11.99)\end{array}$ & $\begin{array}{c}1.037 \\
(13.92)\end{array}$ & $\begin{array}{r}1.278 \\
(16.03)\end{array}$ & $\begin{array}{r}1.275 \\
(15.91)\end{array}$ \\
\hline Log_DTAit & & $\begin{array}{l}0.385 \\
(2.89)\end{array}$ & $\begin{array}{l}0.737 \\
(4.38)\end{array}$ & $\begin{array}{l}0.560 \\
(3.04)\end{array}$ & & $\begin{array}{l}0.240 \\
(1.57)\end{array}$ & $\begin{array}{l}0.280 \\
(1.85)\end{array}$ & $\begin{array}{l}0.277 \\
(1.82)\end{array}$ \\
\hline Log_DTLit & & $\begin{array}{l}-1.37 \\
(-4.93)\end{array}$ & $\begin{array}{l}-2.205 \\
(-6.16)\end{array}$ & $\begin{array}{l}-2.165 \\
(-6.06)\end{array}$ & & $\begin{array}{l}-0.828 \\
(-8.09)\end{array}$ & $\begin{array}{l}-1.143 \\
(-7.23)\end{array}$ & $\begin{array}{l}-1.141 \\
(-7.03)\end{array}$ \\
\hline Log_CFOit & & $\begin{array}{l}0.101 \\
(2.40)\end{array}$ & $\begin{array}{l}0.113 \\
(2.73)\end{array}$ & $\begin{array}{l}0.280 \\
(2.85)\end{array}$ & & $\begin{array}{l}0.090 \\
(3.06)\end{array}$ & $\begin{array}{l}0.069 \\
(2.48)\end{array}$ & $\begin{array}{l}0.074 \\
(2.28)\end{array}$ \\
\hline Log_Eitlog_DTAit & & & $\begin{array}{l}-2.316 \\
(6.04)\end{array}$ & $\begin{array}{c}-2.76 \\
(-6.46)\end{array}$ & & & $\begin{array}{l}-3.037 \\
(-7.39)\end{array}$ & $\begin{array}{l}-3.044 \\
(-7.94)\end{array}$ \\
\hline Log_Eitlog_DTLit & & & $\begin{array}{c}4.30 \\
(2.57)\end{array}$ & $\begin{array}{c}4.40 \\
(2.96)\end{array}$ & & & $\begin{array}{l}1.071 \\
(2.38)\end{array}$ & $\begin{array}{l}1.073 \\
(2.28)\end{array}$ \\
\hline Log_CFOitlog_DTAit & & & & $\begin{array}{l}0.943 \\
(2.54)\end{array}$ & & & & $\begin{array}{c}-0.122 \\
(0.38)\end{array}$ \\
\hline
\end{tabular}

ISSN: 0010-8189

(C) CONVERTER 2020

www.converter-magazine.info 


\begin{tabular}{c|c|c|c|c|c|c|r|r}
\hline Log_CFOitlog_DTLit & & & & $\begin{array}{c}-2.059 \\
(-2.51)\end{array}$ & & & & $\begin{array}{c}-0.327 \\
(0.78)\end{array}$ \\
\hline R2 & 0.697 & 0.707 & 0.719 & 0.722 & 0.446 & 0.489 & 0.522 & 0.522 \\
\hline
\end{tabular}

\section{Conclusion and Enlightenment}

\subsection{Research Conclusion}

7.1.1. There is a long-term correlation between deferred income tax accounting information and stock price We use long-term data to conclude that there is still a correlation between net assets per share, earnings per share and stock price after excluding deferred income tax accounting information, and the impact on stock price is positively correlated.There is also a long-term correlation between deferred income tax accounting information and stock price. Single analysis shows that the impact of DTAs on stock price is positive, while the impact of DTLs on stock price is negative, which is consistent with the previous research results of scholars using short-term data, indicating that there is a consensus on the research conclusions of deferred income tax accounting information at present. In addition, the empirical results also show that the goodness of fit R2of regression equation is improved after adding deferred income tax accounting information, which shows that the overall explanatory ability of the model is improved, and proves that the deferrability of deferred income tax can affect the value relevance of deferred income tax accounting information.

7.1.2. EPS adjust the correlation between deferred income tax accounting information and stock price

Although deferred income tax items are related to price, the interpretation of future profitability brought by deferred income tax items cannot only look at a single indicator, and the long-term relevance of deferred income tax accounting information will be affected by other factors.

Further research shows that although DTAs will have an impact on stock prices, the higher the DTAs, the better the future earnings of enterprises. When the company's earnings per share are good, the excessive DTAs have a negative impact on the stock price; When EPS is low, DTAs will play a more obvious role in playing its favorable signal, reflecting the future profits of enterprises, which is positively correlated with the company's stock price. However, due to the "deferred" nature of DTAs, whether they can realize the inflow of future economic benefits depends on whether the enterprise can achieve sufficient taxable income in the future. If the actual situation of the enterprise, If the profitability is poor, then a large number of DTAs can not represent the future income, but will show the motivation of earnings management.

Through research, we also find that DTLs have a negative impact on stock prices, but the adverse impact brought by the accumulation of DTLs will also be affected by the level of earnings per share. If EPS of the current enterprise is high, although the DTLs will have a negative impact on the stock price, the negative impact of DTLs on the stock price is relatively small because EPS reflect the strong profitability of the enterprise and absorb the negative impact of DTLs; If the current earnings per share is low, the DTLs will have a great impact on the stock price. The more DTLs, the greater the stock price of enterprises.

7.1.3. CFO adjusts the correlation between deferred income tax accounting information and stock price Whether the DTAs can realize "income" is closely related to whether the enterprise's operating activities can generate enough cash flow. When the net cash flow of the enterprise's operating activities is low, the enterprise's "hematopoietic" ability is weak, and a large number of DTAs are not a real income-generating project, which has almost no impact on the stock price, and even produces downward Only when the net cash flow from business activities is sufficient, the DTAs can be truly guaranteed, which can bring future cash inflow to enterprises, thus bringing positive information and raising stock prices.

The impact of DTLs on stock prices is negative, and the increase of DTLs will lead to the decline of stock prices. Compared with the decline of stock prices when the CFO is small, when the CFO is large, the market is more

ISSN: 0010-8189 
sensitive to the negative impact of DTLs, and the price declines Faster.

\subsection{Management Inspiration}

7.2.1 Set up a warning line for enterprises with abnormal growth of deferred income tax accounting information and publish it

In order to effectively prevent enterprises from whitewashing their financial situation through deferred income tax accounting information, the regulatory authorities of listed companies should pay attention to the growth of deferred income tax accounting information for a long time and conduct regular inspections. If an enterprise conducts earnings management by adjusting accounting behaviors such as accrual items, the accounting information of deferred income tax will be reflected accordingly, so it can be used as a tool for us to observe earnings management behavior. Regulatory authorities should actively prevent enterprise managers from managing earnings through deferred income tax accounting information, let alone use it as a regulator to control profits. If enterprises find abnormal growth of deferred income tax accounting information, they should set up a warning line and publish it, incident and avoid unnecessary losses to the country and investors.

\subsubsection{Accounting information users should pay rational attention to DTAs and DTLs}

From the empirical analysis of this paper, it is concluded that deferred income tax accounting information can indeed improve the relevance of accounting information. When making investment decisions, users of accounting information can not only refer to the traditional financial indicators such as net assets and net profit, but also pay attention to the newly added DTAs and other information. However, when analyzing, we should rationally interpret deferred income tax in accounting statements the information of assets and DTLs, combined with earnings per share, net cash flow of operating activities per share and other related indicators, can adjust the accounting information of deferred income tax, and analyze the specific content of the formation of deferred income tax accounting information in different industries, so as to make a more reasonable and accurate forecast for enterprises.

7.2.3 Accounting personnel's ability to understand and apply the new income tax standards should be further improved

Because the accounting standards for enterprises do not put forward very clear requirements, in the specific operation process, the factors such as the confirmation time, confirmation amount, reversal time and reversal amount of DTAs and DTLs are not uncontrollable. If enterprises deliberately operate them, earnings management behavior will often appear at this time. Listed companies should constantly improve the comprehensive quality and theoretical accomplishment of accounting personnel, let accounting personnel learn to analyze, judge, synthesize and summarize, cultivate a good thinking habit, update their knowledge structure in time, grasp the new situation of continuous development and change, learn modern economic analysis methods, continuously improve accounting professional judgment ability, and strictly guard against insiders. Manipulating earnings behavior, improving accountants' ability to understand and apply income accounting standards, making more accurate professional judgments, and not blindly calculating deferred income tax accounting information, can provide more reliable income tax accounting information.

\section{Acknowledgement}

The paper was supported by (1)General Project of Philosophy and Social Science of Jiangsu Province in China (2020SJA2099), (2)The Humanities and Social Science Youth Program of the Ministry of Education, in China (20YJC630061).

\section{References}

[1] FASB, "Statement of Financial Accounting Standard NO.109, Accounting for Income Taxes," Financial Accounting Standards Board, pp. 76-226, 1992.

[2] IASB, "International Accounting Standard 12-Income Tax," International Accounting Standards Board,

ISSN: 0010-8189 
pp.165-195, 1996.

[3] Accounting Department of Ministry of Finance, "Explanation of Accounting Standards for Business Enterprises 2008," Beijing People's Publishing, pp. 61-66. 2011.

[4] WH Beaver, E. Dukes, "Interperiod tax allocation, earnings expectations and the behavior of security prices," Accounting Review, vol. 47, no. 2, pp. 320-332, 1972.

[5] G Dan, C. Hayn, "The valuation of the deferred tax liability: Evidence from the stock market," Accounting Review, vol. 67, no. 2, pp. 394-410, 1992.

[6] E Amir, M Kirschenheiter, K. Willard, "The valuation of deferred taxes," Contemporary Accounting Research, vol. 14, no. 4, pp. 597-622, 1997.

[7] C. Ayers Benjamin, "Deferred Tax Accounting Under SFAS No.109: An Empirical Investigation of its Incremental Value-Relevance Relative to APB No.11," The Accounting Review, April vol. 73, no. 2, pp. 195-212, 1998.

[8] Chang Cheryl, Herbohn Kathleen, Tutticci. Irene, "Market's perception of deferred tax accruals," Accounting and Finance, vol. 49, pp. 645-673, 2009.

[9] Lijuan Li, Ganbin Wang, Kai Zhu, "Study on the Value Relevance of Deferred Income Tax Accounting Information,” Journal of Shanghai Lixin Accounting Institute, no. 1, pp. 49-56, 2011.

[10] Lidong Zheng, Xiaoke cheng, Yanyan Xia, "Deferred income tax and stock pricing-empirical evidence based on residual income valuation model," China management Studies, vol. 7, no. 4, pp. 95-113, 2012.

[11] Gaidi, Na Lu, "Study on the Impact of Deferred Income Tax on the Information Quality of Financial Statements," Journal of Beijing Technology and Business University (Social Science Edition), no. 2, pp. 52-61, 2014.

[12] Chandra Uday, T. Ro Byung, "The Association between Deferred Taxes and Common Stock Risk," Journal of Accounting and Public Policy, no. 16, pp. 311-333, 1997.

[13] Beckman Judy, Brandes Christina, and Eierl. Brigitte, "German reporting practices: An analysis of reconciliations from German Commercial Code to IFRS or U.S. GAAP,” Advances in International Accounting. vol. 20, pp. 253-294, 2007.

[14] Astrid K. Chludek. "Perceived versus Actual Cash Flow Implication of Deferred Taxes-An Analysis of Value Relevance and Reversal under IFRS,” Journal of International Accounting Reserach, vol. 10, no. 1, pp. 1-25, 2011.

[15] Deming Dai, Yu Tang, Lijun He, "Double-edged function of deferred income tax accounting information-A case study based on vanadium and titanium at Pangang, " Finance and Accounting, no. 9, pp. 8-13, 2013.

[16] Gai Di, Lu Na, "Research on the influence of deferred income tax on the information quality of financial statements, ” Journal of Beijing Technology and Business University (Social Science Edition) vol. 10, no. 2, pp. 52-61, 2014.

[17] Shuangting Wan, Qingshi Hu, "Analysis on the Rationality of DTAs Recognition," Cooperative Economics and Science, no. 7, pp. 113-115, 2018.

[18] Peigen Li, Rong Li, "Research on the Value Relevance of Accounting Information under the View of Assets and Liabilities," Accounting Research vol. 10, no. 4, pp. 32-35, 2011.

[19] Ball, Brown, "An Empirical Evalution of Accounting Income Numbers," Journal of Accounting Research, no. 6, pp. 159-178, 1968.

[20] Beaver, Clarke, Wright, "The Association between Unsystematic Security Returns and the Magnitude of Earnings Forecast Terrors," Journal of Accounting Research, no. 17, pp. 316-340, 1979.

[21] Ohlson, James A, "Earnings, book values, and dividends in equity valuation," Contemporary Accounting Research: Spring, vol. 11, no. 2, pp. 661-687, 1995.

[22] H. William Beaver, A. Paul Griffin, \& R. Landsman Wayne, "The incremental Information Content of Replacement Cost Earnings," Journal of Accounting and Economics no. 4, pp. 15-39, 1982.J

[23] Shiqiang Mei, Tianyang Wang, "Empirical analysis of the correlation between stock prices and financial indicators of Chinese listed companies," Journal of Dalian Maritime University (Social Science Edition), no. 6 , pp. 52-56, 2014. 